\title{
Study on Effectiveness of Lecture and Smart Class Method of Teaching on Academic Achievements among Upper Primary School Students
}

\author{
Poonam Bala ${ }^{1, a^{*}}$, Tanivir Kaur ${ }^{2, \mathrm{~b}}$, Maninder Kaur ${ }^{3, \mathrm{c}}$ \\ ${ }^{1}$ Lecturer, Child Health Nursing, SION, Punjab-144514 India \\ ${ }^{2}$ Student SION, Punjab-144514 India \\ ${ }^{3}$ Student SION, Punjab-144514 India \\ abpoonam21@yahoo.com*, bdeepgillg0@gmail.com, 'basramaninder33@gmail.com
}

Keywords: Lecture method teaching, Smart class method teaching, academic achievements, upper primary school students.

\begin{abstract}
This is an experimental study conducted on the upper primary school students in the district of S.B.S Nagar, Punjab. The study was conducted on the students of $6^{\text {th }}$ and $7^{\text {th }}$ class of an international School. Total of 100 students were enrolled for this experimental study who met the inclusion criteria and were randomly divided into 2 equal groups by simple randomization technique. They received either the lecture method teaching or the smart class method teaching. For conducting the experiment, the investigator used pre-test and post-test comparison group design. For collection of data, a structured questionnaire and a structured teaching programme was used. t-test was used for analysis and interpretation of the data. The results of the study revealed that the lecture method of teaching was more effective as compared to a smart class method of teaching.
\end{abstract}

\section{Introduction}

Education is a lifelong process and it permeates every aspect of an individual's life. It is a process to shape the quality of life which enhances the quality of society and the universe as a whole. A school is an institution designed for teaching the students under the direction of teachers.

In ancient times, students used to stay in Gurukuls where the teachers had full time and responsibility to shape their life for their betterment and the society. Then the system changed with the time to schooling where students went for specific period and teachers delivered lecture and used blackboard and chalk for making the students understand the subject better. In this traditional approach, teachers shouldered most of responsibility for teaching in the classroom to make sure everything they taught were understood by the students in the limited period of time.

The lecture method is one of the several teaching methods, though in schools it's usually considered the primary one. This method is convenient and usually makes the most sense, especially with larger classroom size. Lecturing lets professor address most people at once. This method allows the instructor to precisely determine the aims, content, organization, pace and direction of a presentation. This also can clarify and complement text material. On the other side lecture method requires the instructor to have effective writing and speaking skills. A lecture is a talk or verbal presentation with the help of A.V. aids like black board, charts etc. given by a lecturer, trainer or speaker to an audience. With all the advancement of training systems and computer technology, lecture method is still a backbone widely used in teaching and training at all levels of education.

With the passage of time and technological enhancement, education system has undergone various changes. Teachers started experimenting with the change in teaching method and methodology. The traditional background approach is gradually giving way to more interactive session between the instructor and students. Dynamic progress in information technologies has necessitated the change in educational process. With the recent technological developments, opportunities have emerged to introduce more efficient methods of instruction in the classroom. Multimedia becomes one of the leading means of teaching today. 
One of the new methods of teaching using multimedia is smart class. A smart classroom is a classroom that has an instructor equipped with computer and audio-visual equipment, allowing the instructor to teach using a wide variety of media. These include smart interactive white board, DVD's, PPT's, OHP and more, all displayed through a data projector. [1] Smart class is powered by a vast repository of digital instructional materials exactly mapped to meet with the specific objectives laid out by different state learning standards. [2]

Smart class is a comprehensive solution designed to assist teachers in schools in meeting day to day classroom challenges and enhancing student's academic performance with simple, practical \& meaningful use of technology. It also enables teachers to instantly assess and evaluate the learning achieved by their students in class.

On the other hand, this method has few disadvantages also which makes the use of smart class (technology) quite limited. The disadvantages are the technology used in smart classrooms is very expensive, skilled faculty is required; all teachers cannot use smart technology for teaching. The teachers have to be trained before they can start teaching in smart classroom. Students face difficulty in understanding the topic if smart class teaching is not supplemented with lecture. The other disadvantage of this method is maintenance of electronic gadgets, technical faults.

Each method of teaching has its own advantages and disadvantages. Though lecture method is traditional method of teaching but most of the studies showed that lecture method with chalk and talk is more effective in academic learning than the other advanced methods of teaching which uses advance technology. The present study was conducted to assess the effectiveness of lecture and smart class method of teaching for the academic achievements in the science subject among upper primary school student of selected school.

\section{Objectives:}

To study the difference in the effect of lecture method and smart class method teaching on academic achievement of upper primary school students.

\section{Hypothesis:}

○ $\mathbf{H}_{\mathbf{0}^{-}}$- There exists no significant difference in lecture method versus smart class method of teaching for post-test knowledge score of subjects in selected science subject topic.

- $\mathbf{H}_{1}-$ There exists significant difference in lecture method versus smart class method of teaching for post-test knowledge score of subjects in selected science subject topic.

\section{Materials and Methods}

\section{Sampling}

The study was conducted in an International School, Punjab, North India, with permission of the principal of school in 2016. 100 upper primary school students i.e. students of $6^{\text {th }}$ and $7^{\text {th }}$ standard were enrolled as study subjects by consecutive sampling technique after obtaining written informed consent from the students. Subjects were randomized into 2 groups by using simple random technique (lottery method) and received either lecture method teaching or smart class method teaching group.

\section{Tools and techniques used}

Lecture method teaching group received 45 minutes structured teaching programme (STP) on selected science subject topic through lecture method. Lecture Method of teaching includes detailed oral presentation along with the use of blackboard and other A.V AIDS (Charts). Students in Smart class method teaching group was taught same STP as of lecture method teaching group through smart class method which includes the video presentations to teach the selected science subject topic to the subjects. Students from $6^{\text {th }}$ class were taught 'Garbage in and out' and $7^{\text {th }}$ class students were taught 'Digestive system'. These topics were chosen from their respective science subject syllabus. 
Baseline demographic characteristics of subjects in both the groups were recorded. Pretest was taken with self-administered questionnaire (each questionnaire containing 15 items) on selected science subject topic. After pre-test, structured teaching program on selected science subject topic was administered through lecture method to one group and through smart class to the other group. Immediately after the teaching programme, post-test was taken from the groups with same questionnaire.

\section{Outcome measurement}

The primary outcome measure was to compare the pre-test and post-test knowledge score of subjects in both the groups.

\section{Statistical analysis}

Data was analyzed and Knowledge scores of two groups were compared using independent $t$-test. $p$ value $<0.05$ was considered significant.

\section{Results}

The baseline characteristics of the subjects of each group like age, sex, class etc. are described in table 1. Equal numbers of students were enrolled from both the classes and were equally distributed to receive different teaching programme.

Table 1. Frequency distribution of subjects according to baseline characteristics

\begin{tabular}{|l|l|l|l|l|}
\hline Sr. No. & $\begin{array}{l}\text { Baseline } \\
\text { characteristics }\end{array}$ & $\begin{array}{l}\text { Lecture method } \\
\text { Group (f) }\end{array}$ & $\begin{array}{l}\text { Smart class method } \\
\text { group(f) }\end{array}$ & p- value \\
\hline $\mathbf{1}$ & Age(in years) & & 4 & \\
\hline a) & $9-10$ & 3 & 4 & \\
\hline b) & $11-12$ & 25 & 27 & 1 \\
\hline c) & $13-14$ & 21 & 19 & \\
\hline d) & $15-16$ & 1 & 0 & \\
\hline $\mathbf{2}$ & Sex & & & 1 \\
\hline a) & Male & 30 & 32 & \\
\hline b) & Female & 20 & 18 & \\
\hline $\mathbf{3}$ & Class & & & - \\
\hline a) & $6^{\text {th }}$ class & 25 & 25 & \\
\hline b) & $7^{\text {th }}$ class & 25 & 25 & \\
\hline
\end{tabular}

\section{Results pertaining to knowledge score difference in two groups}

Pre-test and post-test knowledge scores of the subjects were assessed and results presented in table 2.

Table 2. Comparison of pre-test and post-test knowledge scores of subjects in two groups:

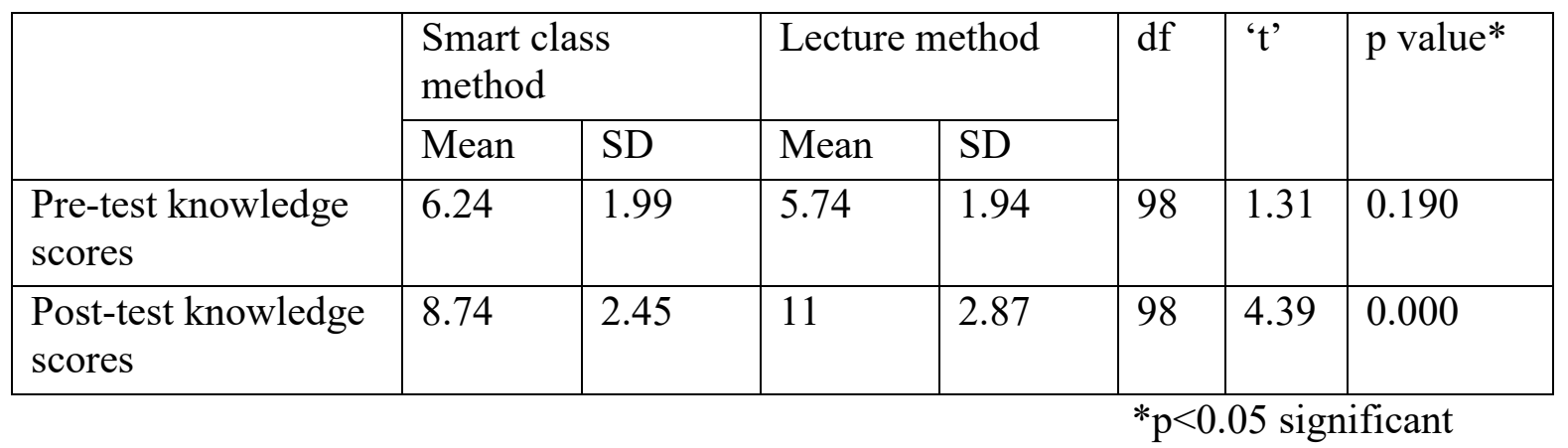


Table 2 depicts comparison of pre-test and post-test knowledge score of subjects in lecture method teaching group and smart class teaching group. Independent t-test was applied to check the significant difference between pre and post-test scores of two groups. Pre-test mean knowledge scores of subjects in smart class method teaching group and lecture method teaching group were $6.24 \pm 1.99$ and $5.74 \pm 1.94$ respectively $(\mathrm{p}=0.19)$ whereas of post-test mean knowledge scores of subjects in smart class method teaching group and lecture method teaching group was $8.74 \pm 2.45$ and $11 \pm 2.87$ respectively $(\mathrm{p}<0.001)$. Therefore, it can be interpreted that there exists significant difference in lecture method versus smart class method of teaching for their post-test knowledge scores of subjects in science subject. Hence, $\mathrm{H}_{\mathrm{I}}$ hypothesis was accepted.

\section{Discussion}

Many studies have demonstrated that lecture method of teaching is more effective method when compared with the other methods. Lecture method using chalk and talk is more beneficial in understanding the topic compared to OHP, PPTs etc. [3-6]

This experimental study showed that lecture method of teaching is more effective method as compared to the smart class method of teaching. A similar study was conducted by S.B. Desa, M.B. Keny [7]. The results of the study showed that students who attended the class choosing chalkboard obtained significantly higher score in MCQ's test as compared to those who attended the same content based lecture using PPT $(\mathrm{p}<0.001)$. The chalkboard lecture was preferred by $67.5 \%$ of the students. [7] In our study also marks scored by students were higher in lecture method teaching group than the smart class method group.

Most of the students also prefer the lecture method of teaching as it helps in better understanding of the concept than PPT [7]. In current study student's preferences and attitude was not assessed due to study nature.

The combination of different teaching methods can be more effective than any single method of teaching. In current study two methods were compared individually i.e. lecture method and smart class method. Only videos were shown in smart class method group and detailed oral presentation with use of chalk board and charts were used in lecture method which helped students to understand the topic better as compared to smart class group subjects. If we combine lecture method with Smart class (PPT, OHP), it can be more effective than lecture method alone. [8]. So, such research studies are recommended for future for assessing effectiveness of combined method of teaching versus single method of teaching.

\section{Main Findings and Conclusion}

There exists a significant difference in the effect of lecture method learning and smart class learning on academic achievement of upper primary school students in science subject. The results show that the students taught through lecture method have scored better than students taught through smart class method. The reasons of performing well by students taught through lecture method may be:

- Lecture method class provides less distractive environment and students are more attentive.

- Lecture method helps to easily memorize the topic as notes and supplementary material provided to the students.

- More organized content.

- Students can clear their doubts in class.

\section{Suggestions}

- Sample size can be enlarged to more concrete results.

- A similar study can be carried on senior secondary level and college level students.

- Comparison can be made between boys and girls.

- Comparison can be made between effectiveness of lecture cum smart class learning vs lecture method alone 


\section{Recommendations}

- Lecture method teaching helps to easily understand the concept and hence improves academic achievement of students.

- The lecture method helps the learner to move at his own pace as it helps the learners to provide individual instruction.

- There are times when whole class discussions are valuable. Summarizing, comparing, and interpreting often involves the whole class. Teachers can use both smart class as well as lecture method in teaching students. The smart class should be supplemented with lecture when required.

- Smart class teaching can be used as supplementary teaching method not as an individual method

\section{References}

[1] Smart classroom in Indian education scenario education essay. Available on https://www.ukessays.com/essays/education/smart-classroom-in-indian-education-scenarioeducation-essay.phpreviewed on March11, 2016

[2] D.D. Agarwal, Educational Technology, 3rd ed., Sarup and Sons, New Delhi, 2005.

[3] N. Amare, To slide ware or not to slide ware: Student's experience with power point versus lecture, Journal of Technical Writing and Communication. 36(3) (2006) 297-308.

[4] R. Chaudhary, P. Dullo, U. Gupta, Attitude of $1^{\text {st }}$ year MBBS medical students about two different audio visual aids in physiology lectures, Pak. J. Physiol. 5(2) (2009) 16-19.

[5] S. Waheeda, K.S. Murthy, A comparative study of blackboard teaching and power point teaching in $1^{\text {st }}$ year medical students, National Journal of Basic Medical Sciences. 6(1) (2015) $11-13$.

[6] R. Prabhu et al., A lecture in medical physiology power point versus chalkboard, South East Asian Journal of Medical education. 8(1) (2014) 72-76.

[7] S.B. Desa, M.S. Keny, Power point versus chalkboard based lectures in pharmacology: Evaluation to their impact on medical student's knowledge and their preferences, International Journal of Advanced Health Science. 1(5 (2014) 10-13.

[8] S.A. Rokade, B.H. Bahetee, Shall we teach anatomy with chalk and board or power point presentations? An analysis of Indian student's perspectives and performance, Scholars Journal of Applied Medical Sciences. 1(6) (2013) 837-842. 